\title{
MOTIVATION TO INNOVATE AS A KEY FACTOR IN INNOVATION DEVELOPMENT PROCESS
}

\author{
Anna Svirina ${ }^{1}$ Ekaterina Polosukhina ${ }^{1}$ \\ Kazan National Research Technical University, Chistopol, Russia, AASvirina@kai.ru
}

\begin{abstract}
Research purpose. The purpose of this study is to analyse the influence of industrial enterprises' employees' motivation to innovate on the results of innovation process and the quality of innovative products market performance. The need for such an assessment was inspired by the lack of understanding the role of motivation to innovate in the quality and success of innovation development process.
\end{abstract}

Design/Methodology/Approach. To achieve this goal, the authors conducted a survey distributed to the industrial enterprise employees. The study was based on the paper-and-pencil survey that was distributed to 250 people involved in innovation development process at Russian industrial enterprises; 150 questionnaires were received back and considered valid for the study. The results were evaluated by means of statistical analysis performed by means of SPSS Statistics software.

Findings. The results support the intuitive proposition that motivation to innovate influences the quality of new product development process: idea generation, market study, product development, pre-commercial financial analysis and commercialisation quality are influenced by motivation to innovate - which is in line with the literature (Cooper, 2013). At the same time, probability on new product development in the company, the quality of initial screening, preliminary technical analysis, preliminary production analysis and in-house product testing do not correlate with employee motivation to innovate. Same is true for the new product performance: we observed no correlation between the motivation to innovate and the market success, whereas correlation was revealed between the innovative motivation and the level of market competition for the new product; however, the graphical analysis allowed to estimate that in case employees with high motivation to innovate are absent in the company, it is very unlikely that the new product would be successful.

Originality/Value/Practical implications. The study was based on a questionnaire that was used for relevant purposes in different countries in order to make cross-country comparison on the innovation development process and the role of motivation to innovate. It allowed to indicate the specific features of organisational culture that are outlined in the Russian management literature: in majority of cases, bottom-level innovative initiatives were not supported by the management (Prigozhin, 2007), and hence, motivation to innovate cannot be revealed by employees at every stage of the new product development process. Another reason for somewhat controversial findings of this study was the difference between organisational cultures of the analysed manufacturing enterprises, which was not evaluated in this article.

Keywords: workplace innovation; motivation for innovation; innovative products development; innovation process; innovation strategy

JEL codes: L22, O31, O32

\section{Introduction}

Existing literature recognises innovation as one of the main drivers of both firm growth and organisational development, which leads to extensive research on key factors affecting efficiency of the process of new product development (see Kahn et al., 2012; Locke \& Wellhausen, 2014), which include, amongst others, individual and team innovation (McMurray et al., 2013), organisational culture (Martins \& Martins, 2002), leadership (Hughes et al., 2018) and a number of other intangible factors. Although motivation to innovate is recognised by a number of scholars as an important incentive of innovation (C) 2020 Authors. This is an open-access article licensed under the Creative Commons Attribution-NonCommercial-NoDerivs License (http://creativecommons.org/licenses/by-nc-nd/3.0/) 
development process (Samila \& Sorensen, 2011) and a key factor of being an industry leader (Moore, 2005), the importance and influence of motivation on innovative process is underdeveloped from the quantitative point of view. Some studies on innovation incentives with large samples were performed recently, but they mainly focus on IT-oriented and other high-tech innovations (Kallingal, Rajarathinam, 2016: Tang, Yu, 2016), thus leaving manufacturing sector innovation behind.

The situation on studying innovation incentives is even worse in case of Eastern European countries: a little evidence on company innovative performance is available (Skorupinska \& Torrent-Sellens, 2014), although the importance of innovation for growth of the firms from this part of the world is clearly recognised (Prats et al., 2015). In case of Russian companies and their innovative activities, a little evidence is revealed so far, which is due to low level of transparency, which is a specific feature of Russian manufacturing sector.

In this study, we aimed to identify the relationship between motivation to innovate and innovation development process based on the data obtained directly from Russian manufacturing companies in order to test the importance of this factor of innovative product performance. A lack of research at the intersect of innovation process, motivation and manufacturing enterprises had defined the research question of this study: does motivation to innovate influence the outcome of innovation development process in the manufacturing sector.

To answer this research question, the authors had implemented a survey on innovation development process, followed by quantitative analysis of the influence of motivation on this process.

\section{Literature overview}

An evaluation of existing literature on motivation to innovate and its influence on company performance and market perspectives of new product showed that the majority of studies are concerned with organisational culture and creativity as drivers of motivation to innovate (Martins \& Martins, 2002), identification of values and assumptions of innovation development (Filipczak 1997, Judge et al., 1997) and the role of openness in promoting innovative motivation (Senge et al, 1994). The problem was also evaluated from managerial point of view: researches investigated the role of learning orientation in creation of motives to innovate (Dragoni et al., 2009) and multidimensional nature of motivation to innovate (Cano-Kollmann \& Hamilton, 2014). Thus the quantitative analysis of the influence of the motivation to innovate on the innovation development process is underdeveloped in existing literature.

An analysis of Russian literature showed lack of quantitative studies on employee motivation, motivation to innovate and innovative products development process and performance. Existing studies paid attention to innovation dynamics (Korzinkov, 2013), implemented theoretical frameworks of innovation process (Gerasimov, 2012), dealt with management of innovation activity (Vasyukhin, Pavlova, 2010) or ranked innovative practices and evaluated relevant methodology (Gokhberg, 2014) and almost all of these studies avoided the use of quantitative data. The reason for low interest towards studying innovative performance, which is named by the country officials a priority of national economy development, can be explained by the fact that innovative products provide less than $1 \%$ of Russian Gross Domestic Product (GDP) (Rosstat, 2014), and the tendency is the same for at least past 10 years (Koshkin, Svirina, 2011). Hence, the problem of innovative product development in Russian context remains underdeveloped in existing literature, which is also due to the lack of interest towards motivation that can be found in Russian management studies.

\section{Methodology}

In order to conduct the research, we used the questionnaire developed for search for workplace innovation and technology innovation by the RMIT university (Xuang, McMurray, 2014), which was enriched by the question on employee motivation to innovate at the time of entering workplace and after a year. The questionnaire was translated into Russian, and the accuracy of translation was tested via reverse translation procedure, and the questionnaire was adapted within two rounds of translation. Then, 250 questionnaires were distributed to mid-Russian manufacturing companies coming from different branches of industry, including chemical and oil industry, construction materials production, equipment 
and accurate equipment building, food manufacturing and ship and engine production. The distribution process took place in September and October 2014. We received back 163 questionnaires filled by managers of different level (a very high response rate of $65.2 \%$ was due to the fact that distribution was made within Russian universities strategic partners' network); 13 appeared to be inappropriate for evaluation, so we got the sample of 150 questionnaires; of these, 128 (85.33\% of the original sample) came from firms that developed new product within the period of past 3 years, whereas the rest confirmed that $14.67 \%$ of original sample work in the companies that did not provide any technology innovation in the past 3 years.

The majority of the companies (which included both small and medium-sized companies (SMEs) and relatively large companies) had launched their latest new product past year, so innovative process in these companies can be considered an innovative flow rather than discrete innovation (although, in $3.1 \%$ of the cases, new product did not get marketed because it was a specific product ordered by a certain client for its purposes). Of those companies, only $1.6 \%$ does not have a procedure for new product development, whereas in $32 \%$ of the cases, there is an informal one, although the majority $-66.4 \%$ of manufacturing firms - have a formal procedure for new product development.

The new product development process was measured in 13 steps developed by Cooper (2013), which evaluated the new product development from idea generation to commercialisation. All response scales for the measures were anchored to a Likert type scale, where $1=$ strongly disagree to $5=$ strongly agree.

\section{Main findings}

To address the main research question of the study, we proposed the following hypothesis:

Hypothesis 1. Motivation to innovate correlates with the elements of new product development process.

Hypothesis 2. Motivation to innovate correlates with the new product performance in the market.

To test hypothesis 1 , we conducted analysis to measure the interrelation between motivation to innovate (at the times of hiring and a year after) and the main indicators of the new product development process (i.e. idea generation, market study, product development, pre-commercial financial analysis and marketing testing).

To test hypothesis 2 we conducted analysis to measure the interrelation between motivation to innovate and the main indicators of the new product development process (i.e. commercialisation and market size of the product).

These hypotheses were tested with correlation analysis performed using SPSS Statistics (see Table 1). The table presents only statistically significant findings.

As it can be seen from the table, hypothesis 1 was partly supported. It was revealed that motivation for innovation and motivation dynamics (the questionnaire studied motivation at the time of employment and after a year of employment) were strongly related to the quality of (1) new product development, (2) idea generation, (3) preliminary market analysis and (4) the level of competition for the developed innovation product. Employee's innovative motivation is also related to the quality of (1) market study, (2) product development process, (3) market testing and (4) commercialisation. Accordingly, one can state that hypothesis 1 was supported by the results of statistical analysis, although some of the correlations did not achieve high level.

At the same time, no relation was observed between the motivation for innovation and (1) the quality of initial screening and (2) new product performance on the market, although intuition suggested these ties should exist (thus hypothesis 2 was not supported). It was confirmed that the absence of employee's motivation for innovation leads to low success rate of innovative products using both correlation and graphical analyses.

The difference identified between the motivation to innovate at the early and late stages (right after starting the job, and a year later) had provoked the need to identify the importance of motivation at both stages of employee performance. 
Table 1. Correlation analysis of new product development process and employee motivation to innovate (Source: author's own findings).

\begin{tabular}{|c|c|c|c|c|c|c|c|c|c|c|}
\hline & & IG & MS & PD & MT & PFI & $\mathrm{C}$ & MSP & MB) & MP \\
\hline $\begin{array}{l}\text { Idea generation } \\
\text { (IG) }\end{array}$ & $\begin{array}{l}\text { Pearson } \\
\text { correlation }\end{array}$ & 1 & $.657^{* *}$ & $.797^{* *}$ & $.719^{* *}$ & $.649^{* *}$ & $.625^{* *}$ & -.004 & $.285^{* *}$ & $.237^{* *}$ \\
\hline $\begin{array}{l}\text { Market } \\
\text { (MS) }\end{array}$ & $\begin{array}{l}\text { Pearson } \\
\text { correlation }\end{array}$ & $.657^{* *}$ & 1 & $.739^{* *}$ & $.706^{* *}$ & $.798^{* *}$ & $.730^{* *}$ & .078 & $.209^{*}$ & $.229^{*}$ \\
\hline $\begin{array}{l}\text { Product } \\
\text { development } \\
\text { (PD) }\end{array}$ & $\begin{array}{l}\text { Pearson } \\
\text { correlation }\end{array}$ & $.797^{* * *}$ & $.739^{* *}$ & 1 & $.692^{* * *}$ & $.752^{* *}$ & $.808^{* * *}$ & .061 & $.241^{* *}$ & $.220^{*}$ \\
\hline $\begin{array}{l}\text { Marketing } \\
\text { testing (MT) }\end{array}$ & $\begin{array}{l}\text { Pearson } \\
\text { correlation }\end{array}$ & $.719^{* *}$ & $.706^{* *}$ & $.692^{* *}$ & 1 & $.835^{* *}$ & $.715^{* *}$ & .057 & $.232^{*}$ & $.236^{*}$ \\
\hline $\begin{array}{l}\text { Pre-commercial } \\
\text { financial } \\
\text { analysis (PFI) }\end{array}$ & $\begin{array}{l}\text { Pearson } \\
\text { correlation }\end{array}$ & $.649^{* *}$ & $.798^{* *}$ & $.752^{* *}$ & $.835^{* *}$ & 1 & $.800^{* *}$ & .070 & $.201^{*}$ & $.195^{*}$ \\
\hline $\begin{array}{l}\text { Commercialisat } \\
\text { ion }(\mathrm{C})\end{array}$ & $\begin{array}{l}\text { Pearson } \\
\text { correlation }\end{array}$ & $.625^{* *}$ & $.730^{* *}$ & $.808^{* *}$ & $.715^{* *}$ & $.800^{* * *}$ & 1 & .034 & $.334^{* *}$ & $.240^{*}$ \\
\hline $\begin{array}{l}\text { How would you } \\
\text { evaluate the } \\
\text { market size for } \\
\text { this new } \\
\text { product? (MSP) }\end{array}$ & $\begin{array}{l}\text { Pearson } \\
\text { correlation }\end{array}$ & -.004 & .078 & .061 & .057 & .070 & .034 & 1 & $.197^{*}$ & $.182^{*}$ \\
\hline $\begin{array}{ll}\text { Motivation } & \text { at } \\
\text { the time } & \text { of } \\
\text { hiring }(\mathrm{MB}) & \end{array}$ & $\begin{array}{l}\text { Pearson } \\
\text { correlation }\end{array}$ & $.285^{* *}$ & $.209^{*}$ & $.241^{* *}$ & $.232^{*}$ & $.201^{*}$ & $.334^{* *}$ & $.197^{*}$ & 1 & $.786^{* *}$ \\
\hline $\begin{array}{l}\text { Motivation } \\
\text { after a year } \\
\text { (MP) }\end{array}$ & $\begin{array}{l}\text { Pearson } \\
\text { correlation }\end{array}$ & $.237^{* *}$ & $.229^{*}$ & $.220^{*}$ & $.236^{*}$ & $.195^{*}$ & $.240^{*}$ & $.182^{*}$ & $.786^{* *}$ & 1 \\
\hline
\end{tabular}

** Correlation significant at .01 .

* Correlation significant at .05 .

The interrelation between the motivation to innovate and the market success of the product is presented in Figure 1.

The graph shows that in case of unsuccessful products, motivation to innovate level was relatively low ( 1 in the questionnaire stood for 'It is absolutely unimportant for me to create innovation in the workplace' and 5 for 'It is very important for me to create innovation in the workplace'), whereas, in case of successful products, at least some of employees stated that the innovation in the workplace was important for them. Hence, hypothesis 2 is partly supported, and the market success of the innovative product appears only when some of the employees are strongly motivated to innovate.

This finding was not unique for the industrial enterprises, yet it was previously confirmed in case of North American and Western European enterprises, whereas the conducted research allowed us to identify that in case of Eastern European and post-Soviet companies, market success of the developed innovative product is related to employees' motivation to innovate. This motivation is in turn related to the quality and efficiency of the new product development process - hence, comes the practical implication of this research - the involvement of efficient personnel in more market successful innovative products would increase the efficiency of the overall innovation process in an industrial enterprise. 


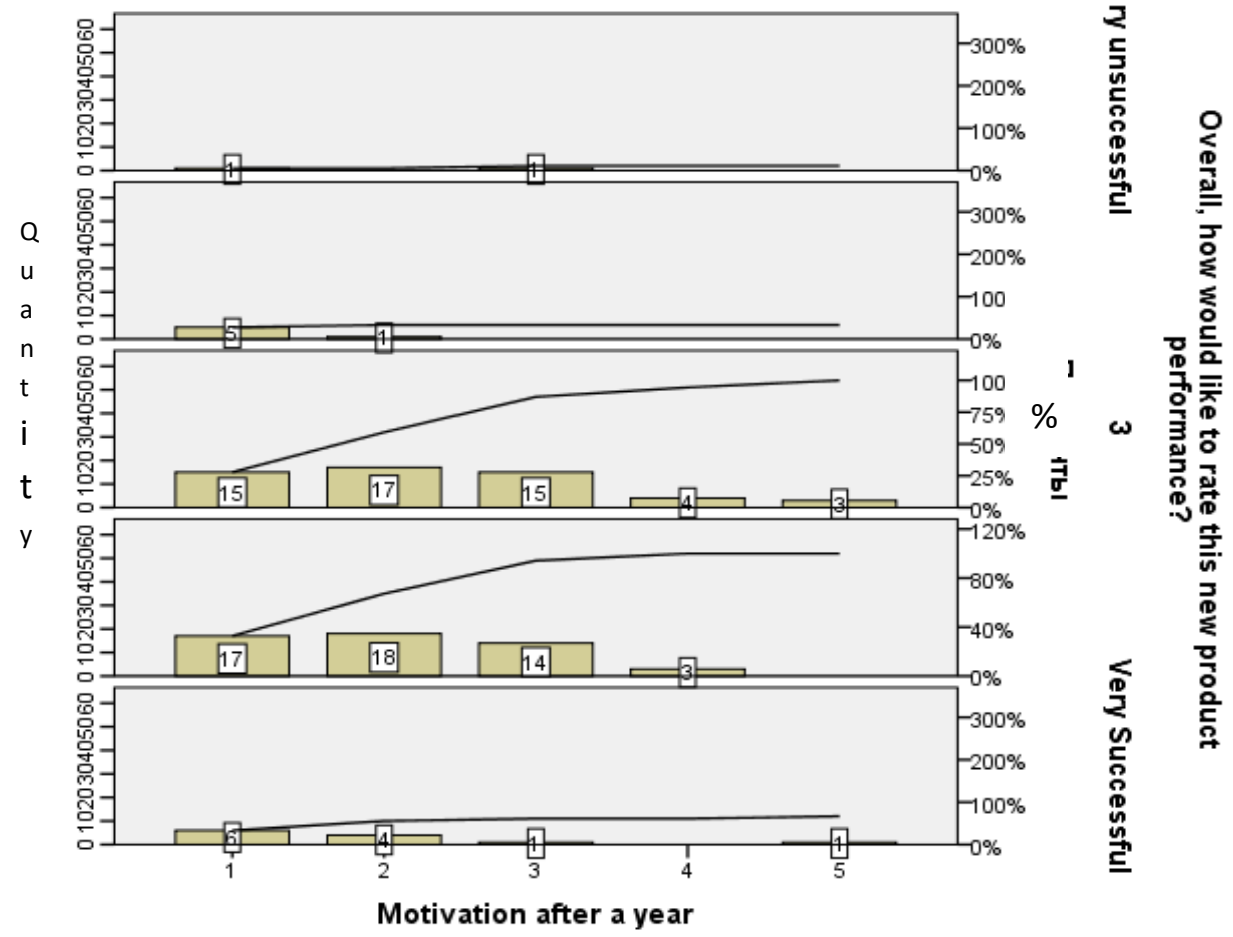

Fig. 1. Graphical analysis of employee motivation to innovate and new product performance (Source: author's own findings)

\section{Conclusions}

The purpose of the study was to measure the relationship between motivation to innovate at the time of hiring and after a year of employment and the elements of new product development process and market performance of innovative products in case of Russian industrial enterprises.

The results supported the intuitive proposition that motivation to innovate influences the quality of new product development process: idea generation, market study, product development, pre-commercial financial analysis and commercialisation quality are influenced by the motivation to innovate - which is in line with the literature (Cooper, 2013). At the same time, probability on new product development in the company, the quality of initial screening, preliminary technical analysis, preliminary production analysis and in-house product testing did not correlate with employee motivation to innovate. Same was true for new product performance: we found no correlation between motivation to innovate and market success, whereas correlation was revealed between innovative motivation and level of market competition for the new product; however, the graphical analysis allowed to estimate that in case employees with high motivation to innovate are absent in the company, it is very unlikely that the new product would be successful.

These findings can be explained by the specific features of organisational culture, which are outlined in the Russian management literature: in majority of cases, bottom-level innovative initiatives were not supported by the management (Prigozhin, 2007), and hence, motivation to innovate cannot be revealed by employees at every stage of new product development process. Another reason for somewhat controversial findings of this study was the difference between organisational cultures of the analysed manufacturing enterprises, which was not evaluated in this article.

Besides the absence of organisational culture evaluation, another major limitation of this study was relatively small sample (which did not include enterprises from Moscow and Saint-Petersburg regions, as well as companies from Asian part of Russia) and its focus was on manufacturing enterprises. These disadvantages indicated that future research should include testing the hypotheses of the study on a bigger sample and in case of other industries as well. 
As the study was originally conducted in 2014, the authors were planning to enrich it by comparative study of the importance of employees' motivation to innovate to the quality of new product development process; the reason behind this was the similar situation in the industry. In 2014, Russian industrial enterprises witnessed increased pressure because of the increased volume of production (regarding to imposed sanctions), whereas in 2020, IT industry is witnessing similar stress provoked by the increased volume of Internet-based operations (evolved because of to COVID-2019-related curfew).

\section{Acknowledgements}

The authors acknowledge the support provided by Dr. A. McMurray and Dr. C. Xuang from the RMIT university for data collection.

\section{References}

Cano-Kollmann, M., Hamilton, R. (2014) Public incentives to innovate and open innovation strategies. Academy of Management Proceedings. doi:10.5465/AMBPP.2014.12250

Cooper, R. G. (2013). Where Are All the Breakthrough New Products? Research Technology Management, 56, 25-33.

Dragoni, L., Tesluk, P, Russel, J., Oh. I.-S. (2009). Understanding Managerial Development: Integrating Developmental Assignments, Learning Orientation and Access to Developmental Opportunities in Predicting Managerial Competences. Academy of Management Journal, Vol. 52, No. 4. pp. 731-743.

Filipczak, B. (1997). It takes all kinds: Creativity in the work force. Training, 34 (5), 32-40

Gerasimov, A. (2012). Problems of increasing efficiency of innovative activity. Retrieved from http://innov.etu.ru/innov/actual.nsf/aac7d56ca8fd884b852563be00610639/51ebfa719430031243256e9f0041786 7/\$FILE/_f0n1gbp85u02u01fh0nk0br05to2u4_.doc

Gokhberg, L. (2014). Innovation in Russian Federation regions. Retrieved from http://www.hse.ru/data/2014/03/13/1331981158/Innovation\%20in\%20the\%20RF\%20regions.2nd\%20edition.pdf

Hughes D., Lee A., Tian A., Newman A., Legood A. (2018). Leadership, Creativity and Innovation: a Critical Review and Practical Recommendations. The Leadership Quarterly, \#2.

Judge, W.Q., Fryxell, G.E. \& Dooley, R.S. (1997). The new task of R \& D management: Creating goal-directed communities for innovation. California Management Review, 39 (3), 72-85

Kahn K., Barczak G., Nicholas J., Ledwith A., Perks H. (2012). An Examination of New Product Development Best Practice. Journal of Product Innovation Management 2:29 (2). Pp. 180-192.

Kallingal A., Rajarathinam M. (2016) Employee Motivation to Innovate and Resources Management: the Mediating Role of Organizational Commitment. International Journal of Modern Concepts and Philosophy. Vol. 9 (3) p. 185

Korzinkov, A. (2013). Corporate innovation management. Evaluation of Russian corporations experience and global environment: current state and recommendations. Retrieved from http://irdclub.ru/wpcontent/uploads/2014/08/CorporateInnovations-_KorznikovAM_201405.pdfSamila, S., Sorensen, O. (2011). Noncomplete Covenants: Incentives to Innovate or Impediments to Growth. Retrieved from http://dx.doi.org/10.1287/mnsc.1100.1280.

Koshkin. L., Svirina, A. (2011). State Management of Intellectual Property in Scientific and Technology Sphere. Ekonomika i upravlenie sobstvennostyu. \#4.

Locke R., Wellhausen R. (2014). Production in the Innovation Economy. MIT Press.

Martins, E., Martins, N. (2002). An Organizational Culture Model to Promote Creativity and Innovation. SA Journal of Industrial Psychology. 28 (4) pp. 58-65.

McMurray, A. J., Islam, M. M., Sarros, J. C. \& Pirola-Merlo, A. (2013). Workplace Innovation in a Nonprofit Organization. Nonprofit Management \& Leadership, 23, 367-388.

Moore, J. (2005). Dealing with Darwin: How Great Companies Innovate at Every Phase of Their Evolution. New York: Portfolio. 
Prats, J., Sosna M., Sysko-Romanczuk A. (2015). Entrepreneurial Icebreakers: Insights and Case Studies from Internationally Successful Central and Eastern European Entrepreneurs. London: Palgrave MacMillan.

Prigozhin A. 2007. Disorganization: reasons, types, ways to overcome. Moscow: Alpina Business Books.

Rosstat. 2014. Russian statistical survey. Moscow: Rosstat.

Senge, P., Kleiner, A., Roberts, C., Ross, R., Roth, G. \& Smith, B. (1999). The dance of change: The challenges of sustaining momentum in learning organizations. A fifth discipline resource. London: Nicholas Brealy.

Skorupinska, A., Torrent-Sellens, J. (2014) ICT, Innovation and Productivity: Evidence from Eastern European Manufacturing Firms. Retrieved from http://journals.uoc.edu/index.php/in3-working-paperseries/article/view/n14-skorupinska-torrent-sellens/n14-skorupinska-torrent-sellens-en

Tung F., Yu, T. (2016) Does Innovation Leadership Enhance Creativity in High-tech Industries. Leadership \& Organization Development Journal. Vol. 37 (5). Pp. 579-592.

Vasyukin, O., Pavlova E. (2010). Industrial enterprise potential development. Moscow: Academia Estestvoznania.

Xuang, C., McMurray, A. (2014). Innovation in the manufacturing industry. Questionnaire. RMIT. 